\title{
ENKELE ASPECTEN VAN BELEIDSVORMING EN BELEIDSVERANTWOORDING
}

\author{
door Dr. Th. P. van Hoorn
}

Dit proefschrift bestaat uit een selectie uit reeds eerder - in het tijdperk 1974 . 1978 - uitgebrachte publicaties in diverse tijdschriften, themanummers, bundels e.d. Zowel de oorspronkelijke totstandkoming als de voor dit proefschrift gemaakte selectie vloeien voort uit mijn belangstelling voor en practische betrokkenheid in adviesrelaties bij vraagstukken van beleidsvorming en beleidsverantwoording gedurende de afgelopen ca. 15 jaar.

Als gevolg van deze wijze van totstandkoming vormt dit proefschrift derhal. ve niet één samenhangend geheel in de zin van een bundeling van deelverslagen van één groot onderzoeksproject. De diverse onderdelen zijn niet ge. schreven met de vooropgezette bedoeling later met elkaar in verband gebracht te worden, elk hoofdstuk is min of meer op zich zelf staand.

Beleid in de zin van doelstellingsformulering alsmede keuze van wegen, middelen en uitgangspunten ter realisering daarvan, heeft bestaan zolang er ondernomen is. In dien zin is er niets nieuws onder de zon. De bestudering van beleidsvorming is echter pas van vrij recente datum. De eerste belangrijke ontwikkelingen dateren uit het midden van de jaren zestig en sindsdien heeft de belangstelling voor dit thema een stormachtige groei doorgemaakt. Inmiddels heeft de theorie van de beleidsvorming zich gedifferentieerd naar een aantal deelterreinen, zijn diverse methoden ontwikkeld en is een geheel eigen „beleidsstrategisch" jargon ontstaan. Zowel de zich ontwikkelende reflectie op de - nog korte - historie als het jargon duidt op een begin van volwassenheid als apart vakgebied.

De inleiding poogt niet alleen een verbinding tussen de thema's beleidsvor ming en beleidsverantwoording te leggen maar ook tussen de diverse hoofdstukken, o.m. door de verschillende opvattingen die hierin naar voren gebracht worden in een bepaald tijdsperspectief te plaatsen.

De eerste vijf hoofdstukken van dit proefschrift behandelen deelgebieden van de beleidsvorming, daarin meestal aangeduid met de termen strategie of strategische beleidsvorming. De eerste drie daarvan gaan in het bijzonder in op de systematiek en opbouw van het strategisch besluitvormingsproces. Deze beschrijven op vrij uitvoerige wijze stapsgewijs een practische aanpak voor de tot standbrenging van het strategisch beleid, met name bij middelgrote tot grote ondernemingen. Zij zijn mede gebaseerd op advieservaring bij deze categorie ondernemingen en hebben het karakter van een handleiding daarvoor. Daarbij wordt waar mogelijk en - voorzover toen reeds bekend en bewust aandacht geschonken aan nieuwe inzichten met betrekking tot thema's als: motivatie van de organisatie voor strategievorming, wederzijdse samenhangen tussen organisatiestructuur en strategie, gevaren van ,veradministrering” van strate. gie, portfolio-aspecten, leerprocessen e.d., elementen die thans worden begre- 
pen onder het begrip het strategisch management van een organisatie.

Hoofdstuk $\mathrm{V}$ behandelt een aantal voornamelijk niet-procedurele aspecten van beleidsvorming in vooral kleine en middelgrote ondernemingen. Deze categorie onderscheidt zich in een aantal opzichten van de categorie "groot" waarvoor - helaas - het merendeel van de literatuur geschreven is. Als zodanig kunnen o.m. genoemd worden: een beperkter aantal strategische opties, be perktere middelen (in termen van mankracht, geld, know how enz.), de overwegend practische instelling van het management, een inadequate strategisch relevante informatieverschaffing e.d.

Tezamen leiden deze tot een specifieke strategische problematiek in deze categorie ondernemingen die om geheel eigen oplossingen vraagt. Gezien het belang van deze categorie ondernemingen voor de Nederlandse economie als geheel (qua investeringen, belastingopbrengst, werkgelegenheid, export e.d.) is er veel aanleiding tot verdere studie over deze problematiek.

Hoofdstuk VI besteedt aandacht aan informatie-aspecten bij een belangrijke fase van het strategisch besluitvormingsproces, namelijk die ten behoeve van samenwerking, overname en fusie. Het betreft hier vooral de keuze van de in houd (relevantie) alsmede de bron van de informatie en voorts de wijze van verzameling, verwerking en evaluatie daarvan voor dit doel.

De beleidsverantwoording vormt het tweede deel van deze dissertatie. Sinds de scheiding van leiding en eigendom in de N.V. heeft de nadruk gelegen in de verantwoording door de directie tegenover vermogensverschaffers en - als gevolg daarvan - steeds in financiële termen. Deze relatief eenzijdige oriëntatie staat sinds het midden der jaren zestig in toenemende mate ter discussie. Daar. bij wordt sterk aangedrongen zowel op een uitbreiding van het aantal thema's waarover wordt gerapporteerd, als van het aantal groeperingen (Amerikaans: stakeholders) tegenover wie verantwoording wordt afgelegd. Wellicht het sterkst is in deze stroming het pleidooi voor rapportering over en verantwoording omtrent het sociaal beleid tegenover de werknemers van de onderne ming.

De hoofdstukken VII, VIII en IX hebben deze materie tot onderwerp. Zij be lichten de ontwikkelingsgang sinds 1945 van standpunten omtrent informa. tieverschaffing en/of verantwoording door ondernemingsbestuurders omtrent het gevoerde en te voeren sociaal beleid. Deze rapportering richt zich in eerste instantie op de eigen werknemers doch bereikt daarnaast - gewild of on gewild - ook nog een aantal derden belangstellenden. In deze periode is er spra. ke van een aanmerkelijke verschuiving in standpunten die ook in de praktijk doorwerkt, waarbij tevens de totstandkoming van nieuwe wetten (wet op de $\mathrm{OR}$, enquêterecht enz.) een rol speelt. Een echte verantwoording tegenover de werknemers is er echter nog niet.

Een groot deel van deze rapportering vindt plaats in de bij ons reeds zeer gangbaar geworden sociale jaarverslagen. Op zowel inhoud als vormgeving en opzet is zeer veel kritiek geuit, dikwijls terecht. Inmiddels treden er echter ook aanzienlijke verbeteringen op.

Een belangrijk probleem bij de sociale verslaggeving is onze zeer onvoldoende kennis omtrent quantificeerbaarheid en normeerbaarheid van elementen van sociaal beleid (zgn. sociale kengetallen of indicatoren). Deze zijn in feite een 
conditie om tot toetsbaarheid van het sociaal beleid te komen in het kader van de verantwoording. Een volgende interessante vraag dient zich aan in het ka. der van de voortgaande vermaatschappelijking van onze ondernemingen, en wel of de maatschappelijke component in de strategie van elke (grotere) onderneming, die hier zonder twijfel het gevolg van is, niet zijn neerslag moet vinden in de vorm van verantwoording hierover. De logische stap die hier uit zou moeten voortvloeien, is die naar het maatschappelijk jaarverslag, waarin naast de thans reeds gebruikelijke aspecten gerapporteerd wordt en verant woording wordt afgelegd over maatschappelijk relevante aangelegenheden, zoals milieu- en planologische aspecten, beslag op grondstoffen, energie en wa. ter, consumentenaangelegenheden e.d. 